Website : http://agritek.unmermadiun.ac.id/index.php/agritek

\title{
Pengaruh Lama Perendaman Terhadap Perkecambahan Dan Pertumbuhan Tanaman Palem Raja
}

\author{
Dwi Wahyu Setyaningsih \\ Dosen Fakultas Pertanian, Universitas Soerjo, Jl.Cepu Km 3, Ngawi, 63218 \\ E-mail: kembarjayaleather@gmail.com
}

\begin{abstract}
Plant germination is the beginning of a new individual's growth marked by the appearance of a radicle at the seed testa. This research aims to determine the effect of long immersion towards germination and growth of King Palm. This study used an experimental method with Randomized Block Design (RBD) with 4 treatments and 4 repetitions. Those treatments were treatment of P0 (control), P1 (immersion for 24 hours), P2 (immersion for 48 hours) and P3 (immersion for 72 hours). The data obtained was analyzed by variance analysis and continued with BNT test. Based on observations, King Palm seed germination is hypogeal, because cotyledons (keeping seeds) remain in the soil. King palm seeds with immersion treatment do not significantly affect germination. Likewise, immersion time does not significantly affect the height of shoots aged 55 days after seedling. The treatment of immersion time for King Palm seeds significantly affected the root length at the age of 55 days after seedling. After the BNT test, the effect of immersion towards the root length showed that 48 hours of immersion treatment had the best effect. The 48-hour immersion treatment for the King Palm plant nursery is recommended to be done by ornamental plant farmers and ornamental plant breeders to accelerate the growth process.
\end{abstract}

Keywords —: King's Palm; Germination; Growth; Hypogeal.

\section{PENDAHULUAN}

\section{A. Latar Belakang}

Tanaman hias yang pada saat ini banyak digemari masyarakat yaitu Palem Raja. Tanaman ini selain indah, juga mempunyai sifat mudah ditanam di daerah yang beriklim tropis. Palem Raja termasuk pada jenis tanaman yang ditanam di luar ruangan (outdoor). Disamping itu palem ini banyak diimanfaatkan untuk tanaman peneduh yang ditanam di rumah, pinggir-pinggir jalan kota dan di depandepan gedung.

Palem raja berkembang biak secara generative. Perkembangbiaakan generative berarti tanaman ini menghasilkan buah. Buah palem raja menghasilkan biji yang bisa dimanfaatkan sebagai benih. Sifat buah yang mempunyai kulit biji yang keras, maka untuk pembenihan membutuhkan waktu yang cukup lama. tanaman ini ternyata membutuhkan waktu yang cukup lama. Menurut (Helmidadang, 2012) Biji palem yang telah kering, direndam dalam air selama $12-21$ jam, biji akan berkecambah dalam waktu 3-4 minggu.

Proses perkecambahan benih yang cukup lama ini karena dormansi yang terjadi pada tanaman ini. Dormansi pada biji palem raja disebabkan biji tersebut memiliki endocarp yang keras, tebal dan mengandung minyak sehingga dibutuhkan waktu yang lebih lama untuk berkecambah. Proses perkecambahan dan pembenihan bisa dipercepat dengan memberikan perlakuan tertentu pada biji tersebut.

Mempercepat perkecambahan bisa dilakukan dengan beberapa cara yaitu bisa secara kimia maupun fisika. Perlakuan secara fisika biasanya dengan menggosok/merempelas kulit biji, membuang serabut dari kulit biji dan lain-lain. Secara kimia bisa dilakukan dengan memberikan zat-zat kimia tertentu seperti zat pengatur tumbuh, GA3, KNO3 dan lain-lainnya. Sutopo (1998) menyatakan bahwa banyak cara yang dilakukan untuk mematahkan dormansi, seperti halnya perendaman dengan air, pemberian suhu tertentu dan pemberian zat kimia seperti $\mathrm{H}_{2} \mathrm{SO}_{4}, \mathrm{HCl}, \mathrm{KNO}_{3}$ dan lain-lain.

Contoh penelitian yang pernah dilakukan untuk mempercepat perkecambahan tanaman ini antara lain dilakukan oleh Lestari (2009) bahwa terjadi pematahan dormansi benih palem raja (Roystonea oleraceae jacg) yang direndam dengan $\mathrm{KNO}_{3}, 0.2 \%$ selama 30 menit dan perendaman dengan Giberelin (GA3) 500 ppm selama 52 jam.

Dalam rangka mempercepat perkecambahan dan pertumbuhan, dengan cara, dan bahan yang mudah sekaligus murah, penelitian ini menggunakan air untuk merendam benih tanaman palem raja. Perendaman dilakukan dengan waktu yang berbeda. Hal ini diharapkan dapat mempercepat perkecambahan dan pertumbuhan benih tanaman palem raja.

\section{B. Perumusan Masalah}

Yang jadi permasalahan dalam penelitian ini adalah bagaimana pengaruh lama perendaman dengan air terhadap perkecambahan dan pertumbuhan tunas dan akar palem raja. Tujuan Penelitian : untuk mengetahui pengaruh lama perendaman terhadap perkecambahan dan pertumbuhan palem raja, untuk mengetahui waktu terbaik lama perendaman terhadap perkecambahan dan pertumbuhan palem raja. Manfaat Penelitian : Penelitian ini diharapkan dapat bermanfaat untuk petani tanaman hias dalam rangka pengembangbiakan tanaman palem raja. Hipotesa dalam penelitian ini adalah : lama perendaman mempengaruhi perkecambahan dan pertumbuhan palem raja. waktu perendaman 72 jam mempengaruhi perkecambahan maksimal dan pertumbuhan palem raja. 


\section{TINJAUAN PUSTAKA}

\section{A. Tanaman Palem Raja}

Palem raja dikenal banyak disukai dan ditanam masyarakat karena bentuknya yang menawan dengan batang yang kokoh, daun yang hijau dan segar. Batang palem raja terdapat bekas lingkaran dari pelepah yang tel.ah rontok. Tinggi tanaman mencapai 25- $30 \mathrm{~m}$ (Putu, 2018). Jenis yang banyak ditanam adalah palem raja Kuba. Spesies palem raja yang dikenal adalah Roystonea regia, Roystonea buringuena dan Roystonea elata.

Palem raja berasal dari daerah Amerika dan Karibia. Nama Roystonea diambil dari nama seorang insinyur yang bekerja di kemiliteran AS, Roy Stone. Salah satu anggotanya, $R$. regia biasa ditanam di pinggir jalan atau di taman-taman.

Habitat Palem raja (Roystonea regia) banyak di temukan di pulau Jawa. Palem raja bisa ditemukan di berbagai tempat sampai dan bahkan mampu tumbuh pada ketinggian $1.400 \mathrm{~m}$ di atas permukaan laut.

Berdasarkan klasifikasi secara ilmiah, tanaman palem raja sebagai tersebut:

$\begin{array}{ll}\text { Kingdom } & \text { : Plantae } \\ \text { Divisi } & \text { : Magnoliophyta } \\ \text { Kelas } & \text { : Liliopsida } \\ \text { Ordo } & \text { : Arecales } \\ \text { Famili } & \text { : Arecaceae } \\ \text { Genus } & \text { : Roystonea } \\ \text { Spesies } & \text { : Roystonea regia } \\ \text { Nama Daerah } & \text { : Palem raja } \\ \text { Nama Ilmiah } & \text { : Roystonea regia (Anonimous, 2018) }\end{array}$

\section{B. Deskripsi dan Morfologi Palem Raja}

Palem raja termasuk suku Arecaceae (palem-paleman), merupakan tumbuhan biji tertutup (Angiospermae) yaitu biji buahnya terbungkus danging. Palem raja adalah tumbuhan yang tak bercabang dan tumbuh tegak ke atas. Tumbuhan ini bisa tumbuh hingga mencapai tinggi $20-30 \mathrm{~m}$. (Helmidadang, 2012).

Morfologi Secara Umum Palem Raja:

\section{1) Daun (folium)}

Palem raja mempunyai daun majemuk dengan beberapa anak daun dan berbentuk memanjang. Ujung daun palem raja (Roystone regia) berbentuk runcing. Pangkal Daun berbentuk bundar dengan susunan tulang daun yang menyirip.

Daun palem raja mempunyai warna hijau tua dengan permukaan daun licin.

2) Akar

Palem raja termasuk golongan tumbuhan monokotil dimana akar nya berbentuk akar serabut. Radikula pada bibit terus tumbuh memanjang kearah bawah selama 6 bulan terus menerus dan panjang akar mencapai $15 \mathrm{~cm}$. Akar serabut terdiri dari serabut primer yang tumbuh vertical ke dalam tanah dan horizontal ke samping. Serabut primer ini akan bercabang menjadi akar sekunder ke atas dan ke bawah. Akar sekunder akan tumbuh akarakar baru yaitu akar tersier. Akar serabut cenderung mempunyai kedalam yang tidak terlalu dalam. Untuk palem raja kedalaman akar sekitar 8-16 meter. diun.ac.id/index.php/agritek

3) Batang

palem raja mempunyai batang yang lurus tegak ke atas dan cenderung tidak mempunyai cabang. Tinggi batang bisa mencapai 30 meter dengan bentuk batang yang beruas-ruas. Tanaman palem raja termasuk monpokotil, tidalk memiliki cambium sejati. Saluran pembuluh menyebar di seluruh bagian batang.

4) Bunga

Palem raja mempunyai panikula atau spadiks yang diliputi oleh spata yang bisa mengayu. Setiap bunga uniseksual atau biseksual, (tumbuhan berumah satu), aktinomorf atau sedikit zigomorf, trimer, sepal 3 lepas atau menyatu, valvatus, pada bunga betina, jarang berupa tepal $2+2$, atau perinthium tereduksi atau tidak ada, stamen umumnya 6 dalam 2 lingkaran.

5) Buah

Buah palem raja berbentuk bulat agak oval.. Buahnya biasanya memiliki kulit luar yang relatif tebal, yang menutupi bagian dalam (mesokarpium) yang berair atau berserat. Waktu penyerbukan antara bunga jantan dan bunga betina cukup lama sekitar 5-6 bulan. Buah Palem raja secara anatomi terdiri dari perikaprium yang terdiri dari epikaprium dan mesokaprium, sedangkan yang kedua adalah biji yang terdiri dari endokaprium, endosperm, dan lembaga atau embrio. Epikaprium adalah kulit buah yang kerak dan licin, sedangkan mesokarpium yaitu daging buah yang berserabut mengandung minyak dengan rendemen paling tinggi, Sedangkan lembaga merupakan bakal tanaman.

6) $\mathrm{Biji}$

Biji dilindungi oleh lapisan buah bagian dalam (endokarpium) yang keras dan berkayu. Serat buah dikenal juga sebagai sabut. Di dalam batok terdapat biji yang ketika buah masih muda relatif cair dan berangsurangsur membentuk endapan yang semakin lama mengeras. Endapan ini biasanya mengandung banyak lemak dan protein. Beberapa jenis masih menyisakan cairan di dalamnya.

\section{Manfaat Palem Raja}

Palem raja mempunyai beberapa manfaat antara lain sebagai berikut: Sebagai tanam hias taman, penghias pekarangan rumah, kayu bakar (pelepah) dan pohon penyejuk udara. (Anonimous, 2018)

Manfaat palem dapat dikelompokkan sebagia berikut: Sumber karbohidrat, baik dalam bentuk pati maupun gula contoh aren. sebagai sumber minyak conrohnya kelapa untuk minyak goreng. Daunnya bisa digunakan sebagai bahan anyaman. Banyak jenis palem yang sudah dimanfaatkan untuk tanaman hias jalan. (Anonimous, 2018)

\section{Syarat Tumbuh Palem Raja}

Dalam pertumbuhannya palem raja memerlukan penyinaran matahari penuh alias $100 \%$. Penyemaian atau perkecambahan dan pembibitan sebaiknya jangan terkena sinar matahari langsung (Helmidadang, 2012). Suhu udara yang diperlukan adalah $25-33{ }^{\circ} \mathrm{C}$, dan masih tumbuh baik di luar kisaran suhu udara tropis tersebut. Media tanam tumbuhan ini, tanahnya harus mengandung pasir, dan akarnya tidak menyukai genangan air. (Anonimous, 2014) 
Website : http://agritek.unmermadiun.ac.id/index.php/agritek

Tanaman palem adalah tanaman tropis dan subtropis sehingga selama pertumbuhannya memerlukan sinar matahari penuh. Hanya saja pada saat perkecambahan dan pembibitan sebaiknya jangan terkena sinar matahari yang langsung. Suhu udara yang diperlukan adalah 25-33oC. Media Tanam, Tanah harus mengandung pasir. Selain itu akar tanaman ini tidak menyukai genangan air. Ketinggian Tempat, Tanaman ini dapat tumbuh mulai dari dataran rendah sampai ke dataran tinggi.

\section{E. Media Tanam Pasir}

Pasir sebagai media tanam alternantif menggantikan fungsi tanah. Pasir dianggap layak dan sesuai untuk media tanam dalam penyemaian benih, pembenihan bibit dan perakaran stek batang tanaman. Sifat pasir sebagai media tanam yaitu, cepat kering sehingga mempermudah untuk mengangkat tanaman benih yang akan dipindahkan ke media lain. Media pasir membuat benih bisa tegak karena bobot pasir yang berat apalagi dalam keadaan basah. Pasir mempunyai porositas tinggi, sehingga memudahkan aerasi dan drainage dan mudah sekali ditembus oleh akar.

Kelemahan media pasir adalah: Media pasir menurut Poincelot (1979) tidak mengandung unsur hara, tidak memiliki kapasitas penyangga, kapasitas pertukaran kation kecil.

\section{F. Perkecambahan Dan Pertumbuhan}

a. Perkecambahan

Perkecambahan merupakan tahap awal perkembangan. Embrio di dalam biji yang semula berada pada kondisi dorman mengalami perubahan fisiologis. Embrio akan tumbuh menjadi tumbuhan muda.perkecambahan dapat diartikan sebagai dimulainya proses pertumbuhan embrio dari benih yang sudah matang.(Taiz and Zeiger 1998).

Proses metobolisme biji hingga dapat menghasilkan pertumbuhan dari komponen kecambah (Plumula dan Radikula), dikatakan perkecambahan.

Perkecambahan meliputi peristiwa fisiologis dan morfologis. Proses imbibisi dan absorbsi air, hidrasi jaringan, absorbsi $\mathrm{O} 2$, pengaktifan enzim dan pencernaan, transpor molekul yang terhidrolisis ke sumbu embrio, peningkatan respirasi dan asimilasi, inisiasi pembelahan dan pembesaran sel dan munculnya embrio (Gardner 1991). Syamsuri (2004) menjelaskan bahwa perkecambahan dimulai dengan proses penyerapan air ke dalam sel-sel. Proses fisika yaitu masuknya air pada biji menyebabkan enzim aktif bekerja. Bekerjanya enzim merupakan proses kimia. Enzim amilase bekerja memecah tepung menjadi maltose, selanjutnya maltose dihidrolisis oleh maltase menjadi glukosa. Protein juga dipecah menjadi asam-asam amino. Senyawa glukosa masuk ke proses metabolisme dan dipecah menjadi energi atau diubah menjadi senyawa karbohidrat yang menyusun struktur tubuh. Asam-asam amino dirangkaikan menjadi protein yang berfungsi untuk menyusun struktur sel dan menyusun enzim-enzim baru. Asam-asam lemak terutama dipakai untuk menyusun membrane sel.
Bagian penyusun embrio yang penting pada proses perkecambahan, antara lain:

1) Tunas embrionik, sebagai calon batang dan daun yang dapat tumbuh dan berkembang menjadi bunga dan buah.

2) Akar embrionik, sebagai calon akar yang dapat tumbuh dan berkembang menjadi akar.

3) Kotiledon atau keping biji, merupakan cadangan makanan untuk pertumbuhan embrio hingga mencapai terbentuknya daun, karena embrio tersebut belum menghasilkan makanan sendiri melalui fotosintesis.

Pada umumnya perkecambahan biji melibatkan proses sebagai berikut: (1) absorpsi air, (2) inisiasi pembesaran dan pembelahan sel, (3) peningkatan aktivitas enzimatik, (4) translokasi makanan ke embrio yang tumbuh, (5) peningkatan respirasi dan asimilasi, (6) peningkatan pembelahan dan pembesaran sel, dan (7) diferensiasi sel menjadi jaringan dan organ pada seedling. Proses ini secara keseluruhan dapat dirangkum dalam dua fase: fase hidrasi dan fase aktivasi metabolisme dan pertumbuhan (Sadhu, 1989).

b. Tipe Perkecambahan Palem Raja

Tanaman Palem Raja tergolong dalam tipe perkecambahan hypogeal.

Perkecambahan Perkecambahan hipogeal ditandai dengan epikotil tumbuh memanjang kemudian plumula tumbuh ke permukaan tanah menembus kulit biji. Kotiledon tetap berada di dalam tanah. Contoh tumbuhan yang mengalami perkecambahan ini adalah kacang ercis, kacang kapri, jagung, dan rumput-rumputan embrio (Campbell et al., 2003).

c. Prosentase Perkecambahan

Setiap biji yang dikecambahkan ataupun yang diujikan tidak selalu prosentase pertumbuhan kecambahnya sama, hal ini dipengaruhi daya kecambah benih.

Parameter yang digunakan dapat berupa persentase kecambah normal berdasarkan penilaian terhadap struktur tumbuh embrio yang diamati secara langsung. Secara tidak lansung dengan hanya melihat gejala metabolisme benih yang berkaitan dengan kehidupan benih. Persentase perkecambahan dapat dihitung dengan membagi jumlah benih yang dikecambahkan dengan benih yang bisa berkecambah normal. Perkecambahan dihasilkan oleh benih murni pada kondisi yang menguntungkan dalam jangka waktu yang sudah ditetapkan (Nasrudin, 2009).

Rumus Daya Kecambah:

Daya Kecambah $=$ A/B x 100

A; benih yang berkecambah

B: benih yang ditanam

Rumus perhitungan persentase adalah:

$$
\begin{aligned}
\% \mathrm{BM} & =[\mathrm{BM} /(\mathrm{BM}+\mathrm{BTL}+\mathrm{KB})] \times 100 \% \\
\% \mathrm{BM} & =[\mathrm{BTL} /(\mathrm{BM}+\mathrm{BTL}+\mathrm{KB})] \times 100 \% \\
\% \mathrm{~KB} & =[\mathrm{KB} /(\mathrm{BM}+\mathrm{BTL}+\mathrm{KB})] \times 100 \%
\end{aligned}
$$


d. Faktor Yang Mempengaruhi Perkecambahan

Benih dapat berkecambah bila tersedia faktor-faktor pendukung selama terjadinya proses perkecambahan.

Perkembangan benih dipengaruhi oleh faktor dalam (internal) dan faktor luar (eksternal).

Ketersediaan air merupakan faktor penting. Ada batas minimum serapan air yang harus dilampaui agar perkecambahan dapat berlangsung (Salisbury \& Ross, 1995). Proses perkecambahan dipengaruhi oleh kondisi tempat biji dikecambahkan. Faktor-faktor lingkungan yang berpengaruh adalah air, gas, suhu dan cahaya. Temperatur optimum untuk perkecambahan adalah $34^{\circ} \mathrm{C}$ (Astawan, 2008).

Faktor internal meliputi tingkat kemasakan biji, ukuran biji, absorbansi (daya serap biji terhadap air), dan ada tidaknya zat penghambat. Faktor eksternal meliputi suhu, oksigen, dan air. Cahaya pada proses perkecambahan dapat memengaruhi hormon auksin. Hormon ini rusak atau terurai jika terkena intensitas cahaya yang tinggi. Dengan demikian, pertumbuhan kecambah akan ke arah datangnya cahaya. (Tatang, 2014).

Faktor yang mempengaruhi perkecambahan adalah air, kelembapan, oksigen, dan suhu. Proses perkecambahan dipengaruhi oleh cahaya dan waktu panjang hari. Reaksi cahaya energi tinggi dengan phytochrome menentukan efek fotoperiodik (Copeland \& Miller, 2012).

\section{BAHAN DAN METODE PENELITIAN}

\section{A. Metode Penelitian}

Penelitian dilakukan di green house di Kota Probolinggo. Penelitan dilakukan selama 2 bulan yaitu dimulai tanggal 1 April 2018 sampai 30 Mei 2018.

Metode penelitian yang digunakan adalah penelitian experiment dengan Rancangan Acak Kelompok dengan 4 perlakuan dan 4 kali ulangan. Terdapat 16 pot perlakuan dan setiap perlakuan terdapat 2 biji contoh. $\mathrm{P} 0=$ kontrol (tanpa perendaman air), $\mathrm{P} 1=$ perendaman dengan air selama 24 jam, P2 = perendaman dengan air selama 48 jam dan P3 = perendaman dengan air selama 72 jam.

Peubah yang diamati pada penelitian ini adalah umur berkecambah, tinggi tunas/tanaman dan panjang akar. Data dari semua peubah dianalisis secara statistik dengan menggunakan analisis keragaman, kemudian dilakukan uji beda nyata terkecil (BNT).

Hasil perlakuan berpengaruh nyata atau tidak nyata dapat diketahui dengan membandingkan $\mathrm{F}$ hitung dengan $\mathrm{F}$ tabel. Perlakuan dikatakan berpengaruh tidak nyata bila $\mathrm{F}$ hitung lebih kecil dari $\mathrm{F}$ tabel $0,05 \%$ dan dikatakan berpengaruh nyata bila $\mathrm{F}$ hitung lebih besar dari $\mathrm{F}$ tabel $0,05 \%$. Beda masing-masing taraf perlakuan dapat dilihat, bila perlakuan yang berpengaruh nyata pada uji $\mathrm{F}$ dilanjutkan dengan uji beda nyata terkecil. Rumus uji BNT (W) adalah :
Keterangan :

$\mathrm{r}=$ Ulangan $/$ kelompok

$\mathrm{p}=$ Jumlah perlakuan

$\mathrm{v}=$ Derajat bebas (galat)

$\mathrm{q}=$ Nilai baku q pada taraf uji

\section{B. Bahan (Materi)}

Pada penelitian ini menggunakan biji palem raja yang telah masak yang diambil dari tanaman yang ada di depan TWSL (Taman Wisata Studi Lingkungan) Jl. Basuki Rahmat Kota Probolinggo. Untuk media perkecambahan adalah pasir Lumajang.

a. Pemilihan biji palem

Palem raja diambil dari buah yang sudah tua. Buah yang berwarna merah. Buah yang sudah dipetik dari pohonnya. Buah palem dikupas, dihilangkan daging buahnya sehingga tinggal biji yang sudah bersih Kulit bijinya diretas pada bagian embrio atau lembaga, dijaga jangan sampai lembaganya ikut terkupas. Dipilih biji yang bentuknya mendekati sama, utuh dan tanpa cacat.

b. Pasir Lumajang

Media tanam yang digunakan adalah pasir lumajang atau pasir yang di ambil dari daerah lumajang. Pasir yang sudah sangat terkenal di wilayah Jawa Timur dengan kandungan besi (Fe) tinggi (Nur Aini, 2018).

\section{IV.HASIL DAN PEMBAHASAN}

\section{A. Persentase Perkecambahan Biji Palem Raja}

Menurut beberapa penelitian, rata-rata perkecambahan pada umur 3 sampai 4 minggu. Berdasarkan pengamatan pada penelitian ini didapatkan hasil sebagai berikut; kontrol (tanpa perlakuan apapun) biji.

Persentase perkecambahan berdasarkan pengamatan penelitian menunjukkan bahwa pada control (biji tanpa perlakuan) dalam waktu kurang dari 2 minggu tidak menunjukkan adanya biji yang berkecambah. Pada biji yang mengalami perlakuan lama perendaman baik 24 jam, 48 jam maupun 72 jam persentase perkecambahan lebih tinggi daripada palem mulai berkecambah pada hari ke-19 sampai hari ke-30 setelah semai. Pada perlakuan dengan perendaman selama 24 jam, biji palem mulai berkecambah pada hari ke 11 sampai hari ke-28 setelah semai. Perlakuan dengan perendaman selama 48 jam, biji palem mulai berkecambah pada hari ke -11 sampai hari ke-24 setelah semai. Perlakuan dengan perendaman selama 72 jam, biji palem mulai berkecambah pada hari ke-9 sampai hari ke- 28 setelah semai. Berdasar pengamatan tersebut menunjukkan bahwa biji tanpa perlakuan ternyata membutuhkan waktu lebih lama daripada biji yang telah mengalami perlakuan perendaman. Rekapitulasi rata-rata persentase perkecambahan biji palem raja selama pengamatan disajikan dalam tabel 1.

$$
\mathrm{W} \text { (r.v). Sy dan Sy }=\sqrt{\frac{K T G}{y}}=\frac{s d}{2}
$$


Website : http://agritek.unmermadiun.ac.id/index.php/agritek

Tabel 1.

Hasil perhitungan rata-rata persentase perkecambahan

\begin{tabular}{|l|c|c|c|}
\hline \multirow{2}{*}{ Perlakuan } & \multicolumn{3}{|c|}{ Rata-rata persentase perkecambahan (\%) } \\
\cline { 2 - 4 } & $\begin{array}{l}\text { Kurang dari 2 } \\
\text { minggu }\end{array}$ & $\begin{array}{l}\text { Lebih dari 2 } \\
\text { minggu dan } \\
\text { kurang dari 4 } \\
\text { minggu }\end{array}$ & $\begin{array}{l}\text { Lebih } \\
\text { dari 4 } \\
\text { minggu }\end{array}$ \\
\hline Control & - & 75 & 25 \\
\hline $\begin{array}{l}\text { Perendaman } \\
\text { selama 24 } \\
\text { jam }\end{array}$ & 12.5 & 75 & 12.5 \\
\hline $\begin{array}{l}\text { Perendaman } \\
\text { selama 48 } \\
\text { jam }\end{array}$ & 25 & 75 & - \\
\hline $\begin{array}{l}\text { Perendaman } \\
\text { selama 72 } \\
\text { jam }\end{array}$ & 12.5 & & \\
\hline
\end{tabular}

Kontrol, biji dengan lama perendaman 24 jam menghasilkan biji berkecambah $12,5 \%$, biji dengan lama perendaman 48 jam menghasilkan biji berkecambah $25 \%$ dan biji dengan lama perendaman 72 jam menghasilkan biji berkecambah $12,5 \%$. Persentase berkecambah dalam waktu kurang dari 24 jam paling tinggi pada biji dengan perlakuan perendaman $48 \mathrm{jam}$. Hal ini karena lama perendaman dengan air sudah optimum.

Persentase biji berkecambah dengan waktu lebih dari 2 minggu dan kurang dari 4 minggu ternyata mendapatkan hasil yang paling tinggi yaitu $75 \%$, baik pada control, biji dengan perlakuan perendaman 24, 48 maupun 72 jam. Hal ini karena perendman yang terlalu lama dapat menyebabkan anoksia (kehilangan oksigen), sehingga membatasi proses respirasi. Respirasi merupakan suatu tahapan proses perkecambahan yang terjadi setelah proses penyerapan air. Apabila proses respirasi terbatas maka proses perkecambahan akan berjalan lambat. (Utomo, 2006)

Pada perlakuan perendaman pada biji palem selama 48 jam mendapatkan hasil berkecambah dengan prosentase baik, $25 \%$ berkecambahn kurang dari 2 minggu dan $75 \%$ berkecambah dengan waktu lebih darin 2 minggu dan kurang dari 4 minggu.

Air merupakan kebutuhan mutlak bagi perkecambahan. Tahap pertama perkecambahan adalah penyerapan air dengan cepat secara imbibisi. Air yang berimbibisi menyebabkan biji mengembang dan memecahkan kulit pembungkusnya dan juga memicu perubahan metabolic pada embrio sehingga biji melanjutkan pertumbuhan. Enzimenzim akan mulai mencerna bahan-bahan yang disimpan pada kotiledon dan nutrient-nutriennya dipindahkan ke bagian embrio yang sudah tumbuh. Enzim yang berperan dalam pencernaan cadangan makanan adalah enzim amylase, beta-amilase dan protease. Hormone giberelin berperan penting untuk aktivasi dan mensintesis enzim-enzim tersebut.

Palem raja termasuk tanaman yang berkembang biak dengan biji. Biji akan terjadi perkecambahan, masuk pada tipe perkecambahan hypogeal. Pada perkecambahan ini ditandai dengan tumbuhnya epikotil yang memanjang sehingga plumula keluar menembus kulit biji dan muncul di atas permukaan tanah, sedang kotiledon tertinggal dalam tanah.

\section{B. Pertumbuhan Tanaman Palem Raja}

a. Pertumbuhan Tunas

Berdasar hasil pengamatan pada penelitian ini, tinggi tunas pada hari 55 setelah semai pada setiap perlakuan setelah dilakukan analisa sidik ragam didapatkan hasil yang tidak signifikan.

Namun demikian, dapat diketahui bahwa rata-rata tinggi tunas pada umur 55 hari setelah semai berdasar pengamatan didapat untuk kontrol ( tanpa perlakuan ) sebesar 2,194 $\mathrm{cm}$ dan untuk benih palem raja yang direndam selama 24 jam rata-rata tinggi tunas $3,175 \mathrm{~cm}$, benih yang direndam selama 48 jam, rata-rata tinggi tunas $3,375 \mathrm{~cm}$ dan benih yang direndam selama $72 \mathrm{jam}$, rata-rata tinggi tunas $4,181 \mathrm{~cm}$. meskipun perlakuan perendaman tersebut tidak menunjukkan pengaruh yang nyata namun dari rata-rata tinggi tunas dari setiap perlakuan terdapat perbedaan. Rata-rata tinggi tunas yang paling besar pada perlakuan pereendaman terhadap biji palem selama $72 \mathrm{jam}$. Perbedaan pertumbuhan tunas ini kemungkinan karena perkecambahan terjadi lebih awal disbanding dengan benih tanpa direndam. Perendaman dengan air pada benih berfungsi untuk mempercepat masuknya air atau proses imbibisi pada proses perkecambahan. Sedangkan pada masa pertumbuhan tunas, nutrisi paling banyak didapatkan dari kotiledon (cadangan makanan) yang terdapat pada biji tersebut yang dimanfaatkan untuk pertumbuhan. Dalam hal ini nutrisi yang bersumber dari luar atau dari tanah belum banyak dibutuhkan dalam proses pertumbuhan tunas.

\section{b. Pertumbuhan Akar}

Berdasar pada penelitian ini didapatkan hasil bahwa pertumbuhan akar (panjang akar) pada umur 55 setelah semai, menunjukkan bahwa perendaman berpengaruh nyata terhadap pertumbuhan akar. Hal ini dapat dilihat pada Tabel analisa sidik ragam pada Lampiran 6 . Pertumbuhan akar yaitu panjang akar dipengaruhi oleh lama perendaman pada benih palem raja. Benih yang mengalami perkecambahan lebih awal dimungkinkan pertumbuhan akar lebih cepat karena munculnya nya radikula atau bakal akar lebih cepat disbanding dengan benih yang tidak dilakukan perendaman atau kontrol. Proses perkecambahan diawali dengan munculnya radikula sebagai calon akar dan plumula sebagai calon batang.

Berdasar pengamatan, rata-rata panjang akar yang paling tinggi terdapat pada biji palem dengan perlakuan perendaman selama 48 jam. hal ini kemungkinan karena tumbuhnya radikula terjadi lebih awal karena proses perkecambahan lebih mudah dan lebih awal. Air bisa juga digunakan untuk mempercepat perkecabahan atau mematahkan dormansi, meskipun dalam penelitian ini didapatkan hasil bahwa perendaman dengan air pada benih palem tidak berpengaruh pada perkecambahan. Namun perlakuan perendaman berpengaruh terhadap panjang akar. Hasil pengujian terhadap kelompok menunjukkan $\mathrm{F}$ hitung < $\mathrm{F}$ tabel 5\% dan 1\%. Hal ini berarti pengelompokkan yang dilakukan tidak berhasil 
Website : http://agritek.unmermadiun.ac.id/index.php/agritek

dalam mengendalikan keragaman data akibat non perlakuan pada lingkungan percobaan. Hasil pengujian terhadap perlakuan perendaman pada biji palem raja menunjukkan $\mathrm{F}$ hitung > $\mathrm{F}$ tabel $5 \%$ dan $1 \%$, hal ini berarti perlakuan perendaman dapat memberi pengaruh yang nyata terhadap panjang akar tanaman palem raja. Berdasar uji lanjut BNT, perbedaan pada tiap perlakuan dapat diketahui.

Tabel 2.

Uji BNT 5\% untuk Lama Perendaman Terhadap Panjang Akar Palem Raja.

\begin{tabular}{|l|c|c|}
\hline Perlakuan & Rata-rata & Notasi \\
\hline Kontrol & 5,256 & a \\
\hline Perendaman selama 24 jam & 4,265 & a \\
\hline Perendaman selama 48 jam & 8,838 & b \\
\hline Perendaman selama 72 jam & 9,525 & b \\
\hline
\end{tabular}

Perlakuan perendaman selama 48 jam pada benih palem raja mendapatkan hasil terbaik pengaruhnya terhadap panjang akar tanaman palem raja. Perendaman selama 48 jam lebih efektif dibanding perendaman selama 72 jam. Perendaman dilakukan agar sel-sel yang ada dalam biji dapat aktif tumbuh. (Asdanimuatika, 2012). Helmidadang (2012), biji palem raja yang telah direndam selama $12-21$ jam, akan tumbuh kecambah pada minggu ke 3-4. Pada perendaman terjadi proses penyerapan air yaitu selama proses imbibisi terjadi pertambahan volume dan bobot basah benih. Pertambahan volume benih tersebut sangat cepat pada awa proses imbibisi dan semakin lama pertambahnnya semakin lambat. (Leopold, 1983).

\section{KESIMPULAN DAN SARAN}

\section{A. Kesimpulan}

Berdasar hasil penelitian menunjukkan bahwa perlakuan lama perendaman tidak berpengaruh terhadap waktu perkecambahan biji palem raja. Namun demikian dapat diketahui bahwa rata-rata waktu perkecambahan antara biji dengan perlakuan perendaman cenderung lebih cepat dibanding waktu perkecambahan biji tanpa perlakuan. Persentase perkecambahan terbaik pada perkecambahan biji palem dengan perendaman selama 48 jam, yaitu dalam waktu kurang dari 4 minggu biji sudah mengalami perkecambahan semua $(100 \%)$.
Perlakuan lama perendaman berpengaruh nyata terhadap panjang akar tanaman palem raja umur 55 hari setelah semai. Perlakuan perendaman selama 48 jam pada benih palem raja mendapatkan hasil terbaik pengaruhnya terhadap panjang akar tanaman palem raja.

\section{B. Saran}

Berdasarkan hasil penelitian ini, petani tanaman hias dan pembibit tanaman hias bisa melakukan perendaman terhadap biji palem raja selama 48 jam, karena efektif dilakukan dalam pertumbuhan akar pada pembenihan biji palem raja. Para peneliti bisa melakukan penelitian lebih lanjut tentang dormansi yang dialami biji palem raja.

\section{DAFTAR PUSTAKA}

Anonimous. 2018. Palem Raja. Wikipedia Bahasa Indonesia, Ensiklopedia bebas

Anonimous, 2014. Syarat Tumbuh Tanaman Palem. Kementerian Pertanian. Cybex.pertanian.go.id.

Asdanimuatika, 2012. Kenapa Biji harus Direndam Dahulu Saat Akan Ditanam. https://asdanimuatika.wordpress.com

Campbell, N,A., Reece, J.B., dan Mitchell, L. G.a. 2003. Biologi Jilid 2.Penerbit Erlangga. Jakarta.

Copeland, L. O \& Miller M. 2012. Principles of Seed Science and Technology. Springer. New York. p 72-85.

Ditrias. 2016. Kenali Palem Raja. www.kebunpedia.com > ... > Forum Tanaman > Pohon \& Semak

Gardner, F.P, Pearce, R.B dan Mitchell, L.G, 1991. Fisiologi Tanaman Budidaya. Penerbit ITB. Bandung.

Helmidadang. 2012. Pohon Palem Raja https://helmidadang.wordpress.com/2012/11/.../

ISTA International Rules for Seed Testing. 2006. Switzerland: The International Seed Testing association. Bassersdorf. $\mathrm{CH}$.

Nasrudin. 2009. Evaluasi perkecambahan teknologibenih.blogspot.com/.../evaluasi-perkecambahan-biji.ht...

Nazarudin. 1997. Palem Hias. Penebar Swadaya. Jakarta.

Putu, B. 2018. Palem Raja (Roystonea regia). https://ganeshaflora.wordpress.com

Nur Aini, 2018. Mengapa Pasir Lumajang Jadi Rebutan. https://www.republika.co.id/.../nvvpjb382-mengapa-pasir-lumaja...

Rouf Baharuddin. 2012. Palem Raja (Roystonea Regia). Baharuddinraufsblog.blogspot.com/.../palem-raja-roystonea-regia...

Sadhu, M. K. 1989. Plant Propagation. New Age International. New Delhi.

Salisbury, F.B dan Ross, C.W. 1995. Fisiologi Tumbuhan Jilid III. Penerbit ITB. Bandung.

Sutopo, L. 2002. Teknologi Benih. Malang

Tatang. 2014. Faktor Yang Mempengaruhi Perkecambahan. Tatangsma.com/.../faktor-yang-mempengaruhi-perkecambahan

Witono, J.R.A, Suhatman, N, dkk. 2000. Koleksi Palem Kebun Raya Cibodas. Seri Koleksi Kebun Raya-LIPI Vol. II, No. I, Sindang LayaCianjur. 